\title{
Hubungan antara pemberian kompensasi, gaya kepemimpinan, dan sarana-prasarana dengan motivasi kerja karyawan cleaning service di RSUP Prof. Dr. R. D. Kandou Manado
}

\author{
${ }^{1}$ Lely I. Porotu'o, ${ }^{2}$ John P. Porotu'o, ${ }^{3}$ Lucia C. Mandey \\ ${ }^{1}$ Program studi Ilmu Kesehatan Masyarakat Bidang Minat Kajian Administrasi Rumah Sakit \\ Pascasarjana Universitas Sam Ratulangi Manado \\ ${ }^{2}$ Fakultas Kedokteran Universitas Sam Ratulangi Manado \\ ${ }^{3}$ Pascasarjana Universitas Sam Ratulangi Manado \\ Email: porotuolely@gmail.com
}

\begin{abstract}
As one of health care organizations, a hospital comprehensively covers promotive, preventive, curative and rehabilitative services for the society, therefore, it often faces problems related to the quality of hospital services which is considered inadequate or unsatisfactory. The hospital has medical staff and non-medical staff such as employees at the finance section, cleaning service, front office, and marketing. These non-medical employees have very important responsibilities and they also manage the operational systems of the hospital. This sudy was aimed to assess the relationship between compensation, leadership style, and infrastructure with work motivation of the cleaning service employees at Prof. Dr. R. D. Kandou Hospital, Manado. This was a quantitative study with a cross sectional design conducted from December to February 2017. Respondents were all cleaning service employees as many as 125 people. Analysis of the data consisted of univariate, bivariate, and multivariate analyses using SPSS. The results showed that the significant values of the variables were as follows: compensation provision $(P=0.000)$, leadership style $(P=0.000)$, and infrastructure $(P=0.102)$ in relation with the work motivation of the cleaning service employees. Conclusion: There were significant relationships between the compensation and leadership style with work motivation of cleaning service employees, meanwhile infrastructure had no relationship with that work motivation.
\end{abstract}

Keywords: compensation, leadership style, infrastructure, work motivation

\begin{abstract}
Abstrak: Rumah sakit sebagai salah satu organisasi pelayanan kesehatan yang komperhensif mencakup layanan promotif, preventif, kuratif, dan rehabilitatif bagi seluruh lapisan masyarakat, sering menghadapi permasalahan mutu pelayanan yang dianggap kurang memadai atau memuaskan. Rumah sakit memiliki tenaga medis dan non-medis yaitu antara lain karyawan yang bekerja di bagian keuangan, cleaning service, front office dan pemasaran. Tenaga non-medis juga memiliki tanggung jawab yang sangat penting dalam mengelola sistem operasional rumah sakit. Penelitian ini bertujuan untuk mengetahui hubungan antara pemberian kompensasi, gaya kepemimpinan, dan sarana-prasarana dengan motivasi kerja karyawan cleaning service di RSUP Prof. Dr. R. D. Kandou. Jenis penelitian ini ialah kuantitatif dengan desain potong lintang yang dilaksanakan pada bulan Desember-Februari 2017. Respoden ialah seluruh karyawan cleaning service sebanyak 125 orang. Analisis data terdiri dari univariat, bivariat, dan multivariat dengan menggunakan SPSS. Hasil penelitian menunjukkan bahwa nilai signifikansi pemberian kompensasi $(0,000)$, gaya kepemimpinan $(0,000)$, dan sarana-prasarana $(0,102)$ terhadap motivasi kerja karyawan cleaning service. Simpulan: Terdapat hubungan antara pemberian kompensasi dan gaya kepemimpinan dengan motivasi kerja karyawan cleaning service di RSUP Prof. Dr. R. D. Kandou Manado, sedangkan sarana-prasarana tidak berhubungan dengan motivasi kerja tersebut.
\end{abstract}

Kata kunci: kompensasi, gaya kepemimpinan, sarana-prasarana, motivasi kerja 
Rumah Sakit sebagai salah satu bentuk organisasi pelayanan kesehatan yang komperhensif mencakup program promotif, preventif, kuratif dan rehabilitatif bagi seluruh lapisan masyarakat. Pihak rumah sakit seringkali mengalami permasalahan dalam hal mutu pelayanan yang dianggap kurang memadai atau memuaskan. ${ }^{1}$

Kompensasi sangatlah penting bagi karyawan. Sebagaimana diketahui, karyawan melakukan berbagai aktivitas di dalam perusahan untuk menghasilkan sesuatu yang pada akhirnya bertujuan untuk memenuhi kebutuhan hidup. Suatu pemberian kompensasi baik finansial maupun non-finansial kepada karyawan merupakan faktor penting untuk dapat manarik, memelihara, maupun mempertahankan tenaga kerja bagi kepentingan perusahaan. Gaya kepemimpinan yang baik sangat diperlukan dalam suatu perusahaan karena dapat melakukan suatu inovasi dan dapat mengoordiniasi semua fungsi perusahaan dengan baik dan benar. Oleh karena itu gaya kepemimpinan yang dimiliki oleh seorang pimpinan hendaknya dapat menciptakan integrasi tinggi dan dapat mendorong atau memotivasi karyawan untuk dapat bekerja dengan baik. ${ }^{2}$

Lingkungan kerja adalah keseluruhan sarana dan prasarana kerja yang ada di sekitar karyawan yang sedang melakukan pekerjaan yang dapat memengaruhi pelaksanaan pekerjaan. Pelaksanaan pekerjaan yang dilakukan setiap karyawan jika didukung oleh sarana dan prasarana yang memadai akan dapat memberikan motivasi kerja yang baik pula. ${ }^{3}$

RSUP Prof. Dr. R. D. Kandou merupakan salah satu rumah sakit pemerintah tipe A yang berada di Provinsi Sulawesi Utara. Rumah sakit ini memiliki tenaga medis dan non-medis. Yang termasuk pegawai non-medis di rumah sakit, yaitu antara lain pegawai yang bekerja di bagian keuangan, cleaning service, front office, dan pemasaran. Oleh karena itu, jelaslah bahwa sumber daya manusia (SDM) pada bagian non-medis merupakan SDM penunjang yang tak kalah pentingnya dari SDM medis, sebab pegawai non-medis memiliki tanggung jawab yang sangat penting pula dalam mengelola sistem operasional rumah sakit. ${ }^{4}$

Berdasarkan hasil observasi awal terhadap motivasi kerja cleaning service di RSUP Prof. Dr. R. D. Kandou maka untuk dapat menjadikan sistem operasional berjalan dengan baik maka motivasi kerja dari pegawai perlu diperhatikan, di antaranya ialah kompensasi yang diberikan, gaya kepemimpinan, serta sarana-prasarana. Beberapa faktor tersebut sangat penting untuk menjaga aktivitas pegawai dan akan memotivasi untuk melaksanakan tugas demi menunjang berjalannya operasional rumah sakit.

\section{METODE PENELITIAN}

Jenis penelitian ini ialah survei analitik kuantitatif dengan desain potong lintang. Penelitian dilakukan di RSUP Prof. Dr. R. D. Kandou Malalayang pada bulan Desember s/d Februari 2017. Populasi penelitian ialah seluruh petugas cleaning service sebanyak 125 orang. Instrumen yang digunakan ialah kuesioner yang memuat pertanyaan mengenai karakteristik umum, pemberian kompensasi, gaya kepemimpinan, dan sarana-prasarana. Analisis data yang digunakan yaitu analisis univariat, bivariat dengan uji chi-square (nilai $\alpha=0,05$ dan $\mathrm{CI}=95 \%$ ), dan multivariat dengan uji regresi logistik.

\section{HASIL PENELITIAN DAN BAHASAN}

\section{Analisis univariat}

\section{Gambaran pemberian kompensasi}

Tabel 1 memperlihatkan gambaran karakteristik responden menurut pemberian kompensasi. Responden yang puas dengan pemberian kompensasi sebanyak 71 orang $(56,8 \%)$ dan yang kurang puas dengan pemberian kompensasi sebanyak 54 orang $(43,2 \%)$.

\section{Gambaran gaya kepemimpinan}

Tabel 2 memperlihatkan gambaran karakteristik responden menurut gaya kepemimpinan. Responden yang menjawab baik sebanyak 93 orang $(74,4 \%)$ dan yang 
kurang baik sebanyak 32 orang $(25,6 \%)$

Tabel 1. Gambaran karakteristik responden pemberian kompensasi

\begin{tabular}{ccc}
\hline $\begin{array}{c}\text { Pemberian } \\
\text { kompensasi }\end{array}$ & n & \% \\
\hline Puas & 71 & 56,8 \\
Kurang puas & 54 & 43,2 \\
Total & 125 & 100,0 \\
\hline
\end{tabular}

Tabel 2. Gambaran karakteristik responden menurut gaya kepemimpinan

\begin{tabular}{ccc}
\hline Gaya kepemimpinan & $\mathbf{n}$ & $\mathbf{\%}$ \\
\hline Baik & 93 & 74,4 \\
Kurang baik & 32 & 25,6 \\
Total & 125 & 100,0 \\
\hline
\end{tabular}

\section{Gambaran sarana-prasarana}

Tabel 3 memperlihatkan gambaran karakteristik responden menurut saranaprasarana. Responden yang menjawab memadai dalam hal sarana-prasarana sebanyak 72 orang $(57,6 \%)$ dan yang menjawab kurang memadai sebanyak 53 orang $(42,4 \%)$.

Tabel 3. Gambaran karakteristik responden menurut sarana-prasarana

\begin{tabular}{ccc}
\hline Sarana prasarana & n & \% \\
\hline Memadai & 72 & 57,6 \\
Kurang memadai & 53 & 42,4 \\
Total & 125 & 100,0 \\
\hline
\end{tabular}

\section{Gambaran motivasi kerja}

Tabel 4 memperlihatkan gambaran karakteristik responden menurut motivasi kerja. Responden yang menjawab tinggi dalam pemberian motivasi kerja sebanyak
66 orang $(52,8 \%)$ dan yang rendah dalam pemberian motivasi kerja sebanyak 59 orang $(47,2 \%)$.

Tabel 4. Gambaran karakteristik responden menurut motivasi kerja

\begin{tabular}{ccc}
\hline Motivasi kerja & n & \% \\
\hline Tinggi & 66 & 52,8 \\
Rendah & 59 & 47,2 \\
Total & 125 & 100,0 \\
\hline
\end{tabular}

\section{Analisis bivariat}

Hubungan antara pemberian kompensasi dengan motivasi kerja cleaning service di RSUP Prof. Dr. R. D. Kandou

Tabel 5 memperlihatkan hubungan antara pemberian kompensasi dengan motivasi kerja cleaning service di RSUP Prof. Dr. R. D. Kandou. Hasil penelitian menunjukkan bahwa jumlah responden yang puas dengan kompensasi sebanyak 71 orang $(56,8 \%)$ dengan yang tinggi dalam motivasi kerja sebanyak 60 orang $(48,0 \%)$ dan yang rendah dalam motivasi kerja sebanyak 11 orang $(8,8 \%)$. Jumlah responden yang kurang puas dengan pemberian kompensasi sebanyak 54 orang $(43,2 \%)$ dengan yang tinggi dalam motivasi kerja sebanyak 6 orang $(4,8 \%)$ dan yang rendah dalam motivasi kerja sebanyak 48 responden $(38,4 \%)$. Hasil analisis uji chisquare mendapatkan nilai $P=0,000$ (< $\alpha=0,05)$ yang menunjukkan terdapat hubungan bermakna antara pemberian kompensasi dan motivasi kerja karyawan cleaning service di RSUP Prof. Dr. R. D. Kandou.

Tabel 5. Hubungan antara pemberian kompensasi dan motivasi kerja cleaning service di RSUP Prof. Dr. R. D. Kandou

\begin{tabular}{lccccccc}
\hline \multirow{2}{*}{$\begin{array}{c}\text { Pemberian } \\
\text { kompensasi }\end{array}$} & \multicolumn{9}{c}{ Tinggi } & \multicolumn{2}{c}{ Rendivasi kerja } & \multicolumn{2}{c}{ Total } & \multirow{2}{*}{ Nilai $P$} \\
\cline { 2 - 7 } & $\mathrm{N}$ & $\%$ & $\mathrm{n}$ & $\%$ & $\mathrm{n}$ & $\%$ & \\
\hline Puas & 60 & 48,0 & 11 & 8,8 & 71 & 56,8 & \\
Kurang puas & 6 & 4,8 & 48 & 38,4 & 54 & 43,2 & 0,000 \\
Total & 66 & 52,8 & 59 & 47,2 & 125 & 100,0 & \\
\hline
\end{tabular}


Hasil penelitian ini sejalan dengan penelitian oleh Datta dan Datta ${ }^{5}$ mengenai motivasi dan kepuasan pegawai rumah sakit di Kolkata, India. Jenis penelitian menggunakan pre and post test design secara potong lintang dan dilakukan pada 4 rumah sakit melalui teknik simple random sampling. Sebanyak 100 teknisi dan 100 staf front office diwawancarai mengenai status motivasi dan tingkat kepuasan. Hasil penelitian menunjukkan bahwa staf front office memiliki tingkat kepuasan yang lebih tinggi dibandingkan dengan teknisi; hal ini disebabkan oleh insentif staf front office yang lebih diperhatikan oleh organisasi, termasuk kompensasi kecelakaaan.

\section{Hubungan gaya kepemimpinan dengan motivasi kerja cleaning service di RSUP Prof. Dr. R. D. Kandou}

Tabel 6 memperlihatkan hubungan antara gaya kepemimpinan dan motivasi kerja cleaning service di RSUP Prof. Dr. R. D. Kandou. Hasil penelitian menunjukkan bahwa jumlah responden yang menjawab baik dengan gaya kepemimpinan sebanyak 93 responden $(74,7 \%)$ denganyang tinggi dalam motivasi kerja sebanyak 59 orang
$(27,2 \%)$ dan yang rendah dalam motivasi kerja sebanyak 34 responden $(27,2 \%)$. Jumlah responden yang menjawab kurang baik dengan gaya kepemimpinan sebanyak 32 orang $(25,6 \%)$ dengan yang tinggi dalam motivasi kerja sebanyak 7 orang $(5,6 \%)$ dan yang rendah dalam motivasi kerja sebanyak 25 orang (20,0\%). Berdasarkan hasil analisis uji chi-square didapatkan nilai $P=0,000(<\alpha=0,05)$ yang menunjukkan terdapat hubungan bermakna antara gaya kepemimpinan dan motivasi kerja cleaning service di RSUP Prof. Dr. R. D. Kandou.

Hasil penelitian ini selaras dengan penelitian oleh Suyono ${ }^{6}$ yang menganalisis faktor-faktor yang memengaruhi motivasi kerja karyawan pada Bumdes Suligi Mandiri Desa Suligi Kecamatan Pendalian IV Koto Kabupaten Rokan Hulu. Hasil penelitian menunjukkan bahwa antara variabel kompensasi (X1), lingkungan kerja (X2), kepemimpinan (X3) menunjukkan koefisien yang positif dan sangat kuat, sedangkan koefisien determinasi berganda (R2) dapat dijelaskan oleh faktor variabel kompensasi, lingkungan kerja, dan kepemimpian.

Tabel 6. Hubungan antara gaya kepemimpinan dengan motivasi kerja karyawan cleaning service di RSUP Prof. Dr. R. D. Kandou

\begin{tabular}{|c|c|c|c|c|c|c|c|}
\hline \multirow{3}{*}{$\begin{array}{c}\text { Gaya } \\
\text { kepemimpinan }\end{array}$} & \multicolumn{6}{|c|}{ Motivasi kerja } & \multirow{3}{*}{ Nilai $P$} \\
\hline & \multicolumn{2}{|c|}{ Tinggi } & \multicolumn{2}{|c|}{ Rendah } & \multicolumn{2}{|c|}{ Total } & \\
\hline & $\mathrm{n}$ & $\%$ & $\mathrm{n}$ & $\%$ & $\mathrm{n}$ & $\%$ & \\
\hline Baik & 59 & 27,2 & 34 & 27,2 & 93 & 74,4 & \\
\hline Kurang baik & 7 & 5,6 & 25 & 20,0 & 32 & 25,6 & 0,000 \\
\hline Total & 66 & 52,8 & 59 & 47,2 & 125 & 100,0 & \\
\hline
\end{tabular}

\section{Hubungan antara sarana-prasarana dengan motivasi kerja cleaning service di RSUP Prof. Dr. R. D. Kandou}

Tabel 7 memperlihatkan hubungan antara sarana-prasarana dan motivasi kerja cleaning service di RSUP Prof. Dr. R.D. Kandou. Hasil penelitian menunjukkan bahwa jumlah responden yang menjawab sarana-prasarana memadai sebanyak 72 orang $(57,6 \%)$ dengan yang tinggi dalam motivasi kerja sebanyak 43 orang $(34,4 \%)$ dan yang rendah dalam motivasi kerja sebanyak 29 responden $(23,2 \%)$. Jumlah responden yang menjawab sarana-prasana kurang memadai sebanyak 53 orang $(42,4 \%)$ dengan yang tinggi dalam motivasi kerja sebanyak 23 orang $(18,4 \%)$ dan yang rendah dalam motivasi kerja sebanyak 30 responden $(24,0 \%)$.

Hasil analisis uji chi-square mendapatkan nilai $P=0,102 \quad(>\alpha=0,05)$ yang menunjukkan tidak terdapat hubungan antara sarana-prasarana dan motivasi kerja karyawan cleaning service. 
Tabel 7. Hubungan antara sarana-prasarana dan motivasi kerja cleaning service di RSUP Prof. Dr. R. D. Kandou

\begin{tabular}{lcccccccc}
\hline \multirow{2}{*}{ Sarana-prasarana } & \multicolumn{9}{c}{ Motivasi kerja } & \\
\cline { 2 - 8 } & $\mathrm{n}$ & $\%$ & $\mathrm{n}$ & $\%$ & $\mathrm{n}$ & $\%$ & Nilai $P$ \\
\hline Memadai & 43 & 34,4 & 29 & 23,2 & 72 & 57,6 & \\
Kurang memadai & 23 & 18,4 & 30 & 24,0 & 53 & 42,4 & 0,102 \\
Total & 66 & 52,8 & 59 & 47,2 & 125 & 100,0 & \\
\hline
\end{tabular}

Hasil penelitian ini tidak sejalan dengan penelitian Asniar et al. $^{7}$ yang meneliti faktor-faktor yang berhubungan dengan disiplin kerja pegawai Puskesmas Puriala Kecamatan Puriala Kabupaten Konawe Tahun 2016. Hasil penelitian menunjukkan bahwa dari 40 responden di Puskesmas Puriala terdapat 25 orang $(62,5 \%)$ yang mengatakan sarana dan prasarana yang ada cukup lengkap; hal ini dibuktikan dengan lengkapnya fasilitas kantor baik dari alatalat kesehatan maupun alat-alat yang ada di bagian administrasi sedangkan 15 responden $(37,5 \%)$ mengatakan sarana dan prasarana yang ada di puskesmas Puriala masih kurang; hal ini dibuktikan dengan jumlah fasilitas yang digunakan masih terbatas, dan juga terdapat fasilititas yang tidak bisa digunakan. Dengan adanya kekurangan sarana-prasarana makaa semangat kerja karyawan berkurang sehingga menimbulkan ketidakdisiplinan dalam bekerja. Hasil uji statistik menunjukkan bahwa proporsi responden yang berpendapat sarana-prasarana lengkap dengan disiplin kerja lebih besar dibandingkan responden yang berpendapat sarana-prasarana kurang lengkap dan tidak disiplin kerja.

\section{Hasil analisis multivariat}

Pada uji multivariat diperoleh nilai eksponen beta tertinggi yaitu pemberian kompensasi $(225,997)$ sehingga merupakan variabel yang paling dominan berhubungan dengan motivasi kerja cleaning service di RSUP Prof. Dr. R. D. Kandou (Tabel 8).

Tabel 8. Uji regresi logistik

\begin{tabular}{lccccc}
\hline \multicolumn{1}{c}{ Variabel } & B & S.E. & Wald & Sig. & $\operatorname{Exp(B)}$ \\
\hline Pemberian & 5,421 & 0,943 & 33,049 & 0,000 & 225,997 \\
kompensasi & 3,345 & 0,887 & 14,209 & 0,000 & 28,349 \\
Gaya kepemimpinan & 1,191 & 0,785 & 2,301 & 0,129 & 3,289 \\
Sarana prasarana &
\end{tabular}

\section{SIMPULAN}

Dari hasil penelitian dapat disimpulkan bahwa terdapat hubungan antara pemberian kompensasi dan gaya kepemimpinan dengan motivasi kerja cleaning service di RSUP Prof. Dr. R. D. Kandou. Tidak terdapat hubungan antara sarana-prasarana dan motivasi kerja karyawan cleaning service di RSUP Prof. Dr. R. D. Kandou.

Pemberian kompensasi merupakan variabel paling dominan terhadap motivasi kerja karyawan cleaning service di RSUP Prof. Dr. R. D. Kandou.

\section{SARAN}

1. Dalam rangka meningkatkan motivasi kerja cleaning service, pihak RSUP Prof. Dr. R. D. Kandou harus memperhatikan faktor yang memengaruhi motivasi kerja cleaning service antara lain dengan cara memberikan kompensasi yang sesuai dan adil, memberikan kondisi lingkungan kerja yang nyaman dan aman, serta peran pimpinan dalam berkomunikasi dengan bawahan harus berjalan dengan baik.

2. Kompensasi merupakan variabel yang 
paling dominan terhadap peningkatan motivasi kerja; untuk itu RSUP Prof. Dr. R. D. Kandou harus dapat mempertahankan bahkan meningkatkan kompensasi karyawan dalam bentuk berupa gaji langsung maupun tidak langsung.

3. Dalam hal lingkungan kerja, diharapkan pihak RSUP Prof. Dr. R. D. Kandou agar selalu menciptakan suasana kerja yang kondusif dan harmonis antara atasan dan bawahan maupun sesama cleaning service sehingga suasana kerja menjadi lebih semangat dan diharapkan terciptanya lingkungan kerja yang bersih, aman, dan nyaman. Juga perlu diperhatikan adanya fasilitas-fasilitas pendukung serta keselamatan kerja bagi cleaning service.

\section{DAFTAR PUSTAKA}

1. Hardiansyah Y. Hubungan gaya kepemimpinan kepala ruangan dengan motivasi kerja perawat di Rumah Sakit Umum Daerah Ambarawa. Jurnal STIKES Ngudi Waluyo Ungaran. 2013:1-9. Available from: perpusnwu.web.id.

2. Syah H. Pengaruh kompensasi finansial terhadap kepuasan kerja dan motivasi kerja karyawan pada PT. Graha Raja Empat. Jurnal Ilmu Manajemen. 2013;1(2):462-71.

3. Suwondo DI, Susanto EM. Hubungan lingkungan kerja, disiplin kerja, dan kinerja karyawan. Jurnal Manajemen dan Kewirausahaan. 2015;17(2):13544.

4. Meidian FA. Analisis hubungan faktorfaktor motivasi kerja terhadap disiplin kerja pegawai non medis di gedung administrasi RS X [Skripsi]. Jakarta: Fakultas Kesehatan Masyarakat Universitas Indonesia; 2012.

5. Datta PP, Datta D. A study on motivation and satisfaction of employees in corporate hospital in Kolkata India. Nati J Med Res. 2013;3(1):56-9.

6. Suyono. Analisis faktor-faktor yang mempengaruhi motivasi kerja karyawan pada Bumdes Sugili Mandiri Desa Sugili Kecamatan Pendalian IV Koto Kabupaten Rokan Hulu [Skripsi]. Fakultas Ekonomi dan Ilmu Sosial; 2013.

7. Asniar, Junaid, Tina L. Faktor-faktor yang berhubungan dengan disiplin kerja pegawai Puskesmas Puriala Kecamatan Puriala Kabupaten Konawe. Kendari: Fakultas Kesehatan Masyarakat Universitas Haluoleo; 2016. 